\title{
The Effective Role of Language Supervisor in the Enhancement of Foreign Language Education in Developing Countries
}

\author{
Ahmed Gumaa Siddiek \\ Dawadami Community College - P.O. Box 18, Shaqra University- 11911 Kingdom of Saudi Arabia \\ Email: aahmedgumaa@yahoo.com
}

\begin{abstract}
It is clear today that people all over the globe find proficiency in foreign languages vital in the development of their communities in such a competitive global growing economy, where skilled workforce is an asset in the social and economic growth. The massive bulk of data demands faster and reliable means of access to this knowledge. The realization of this fact has urged governments and individual persons as well, to cater for foreign language education to bridge the physical gap between producers and consumers of knowledge. Foreign language teachers are the frontiers, who are directly concerned to secure and accomplish this mission, so they need to be literate and skillful in their field, by the assistance of language supervisors. Teaching is no longer that simple mechanical job of handing over information from teacher - as active agent to pupil as passive agent. Teaching now is a highly complex job, applying very sophisticated techniques and implement advanced machines to facilitate professional classroom presentation. This paper examines the role of language supervisors-in developing nations-in enhancing the foreign language education as providers of both: core subject knowledge and teaching skills to their supervisees.
\end{abstract}

Index Terms - foreign language education, supervision, effective teaching, knowledge transfer

\section{INTRODUCTION}

\section{A. The Role of the Teacher in the Modern Times}

Teachers were and still are the frontiers that were and still are concerned with imparting knowledge and skills from one generation to another. But this role was -once - tailored for them to carry out as players on the stage, subject to the directions and moods of the stage director. But the modern role of teachers is more important now, as teachers are active factions, who create the events, control them and most of the tome modify their directions. They do not only impart knowledge, but they make it and add much flavor to it. Teaching -in the broad sense- is the job that everybody thinks he can do, but the effective teaching can only be done by professional teachers who like this job and who are trained to do this job, with its pedagogical and technical implications. High quality teaching secures core knowledge and high know-how skills, in this highly sophisticated and refined community of today.

My story with teaching: Teaching was an attractive job, so I found myself involved in doing small business of teaching, where I had my first training with my young brothers and neighbors. But the actual beginning was when I had been contracted to teach English for young people in Saudi Arabia in general education, at the intermediate and secondary schools. As a beginner teacher, I ran into two significant experiences that were to shape my teacher personality. Those experiences equipped me with practical knowledge that I needed, and would be needed by all professional teachers.

As a part of training we had to do some teaching practicum in secondary schools in my country in the Sudan. A teacher supervisor had to follow our teaching development. After each class the group of the trainees was to convene in the supervisor's room to discuss how things had gone in their classes, with their students. Everybody had a story to tell but most of the stories were normal cases. As all the trainees were lacking the techniques of classroom management and learners control, they used to complain from the students' bad behavior in classrooms. The supervisor was to comment on each story and give his advice. He told them that, what all seemed to them as big problems with students, would soon be manageable and drivable in the long run, when they gain teaching experience in the future.

It was my second day. I was assigned to teach literature to grade (1). I had to teach a simplified version of "Flowers for Mrs. Harris". As a part of home assignment, I asked my students to read some pages at home so we could begin the next class by going through the story. Next day I happened to wake up very late as I had been watching an action TV film. I got to bed at the very small hours of the morning. When I was up, there were less than 15 minutes before me, in which I had to go to the bathroom, brush my teeth, have a wash and dress up myself, then take my books and head off to school, which was luckily happened to be separated from our college by a short wall. I did all those things in those 15 minutes, and then I rushed off to school and got into my class in time. I said good morning to my students and wanted to begin my class. But I did not know how to begin, as I had not read the story myself and had not prepared my lesson. Consequently, I had to go a hell of embarrassment. I could not utter one word. I began to lose grounds and sweat began 
to come down from my forehead. I felt very uncomfortable, tied in a very small corner like small wet bird. My students did not take much time to discover that their teacher was not ready, as it was obvious that I hadn't read the story which I had asked them to read. Some students were murmuring, but some were quite daring enough to say it into my face that was a failure! There was no way. I had to admit that I had not prepared my lesson. Luckily and quickly, I was able to change the subject into a football discussion, as it happened that the two major teams Hilal and Merikh were playing a hot match last night. I got out of it, but some bright students were not happy with my performance. Then, I told the whole story to the supervisor that:-

- I jumped over the wall to cut the way short.

- I made a poor presentation because I had not prepared my lessons before getting into class.

- I received very embarrassing remarks from students, because I had not made myself ready, to dress in suitable manner to make good appearance before my students.

- In fact, a young man in the front seat told me that my trousers were unzipped. Truly they were!!!

- I also realized that my shirt was one button down and one button up. Unfortunately it was!!!

- My hair was not that tidy.

- All in all, I was entirely in a real mess.

The man commented that it was one of the best stories he ever had. Then he said that I was very lucky to run such experiences of too many situations during only one day. He said; that experience would make a good teacher out of me. I learned that I had committed many mistakes such as:

- Jumping over the wall: he described it as uncivilized and un-educational behavior. He said it was a thief's behavior not a teacher's.

- The second lesson I learned was to prepare my lessons before getting into the classroom even if I would want to teach an $\mathrm{ABC}$ to beginners.

- The third lesson was I should always have to make acceptable appearance before students - as some people judge one by his coat from the very first look, then they form unforgettable image in their memories.

That was an unforgettable experience which made me take any teaching situations seriously during my entire teaching career, even when conducting an easy lesson to a child. The supervisor's words and advice were always ringing at the back of my years.

The second teaching experience was in Saudi Arabia. It was a turning point in my teaching career. After one month, I was to be visited by the English language supervisor - an Egyptian fellow, by the name Filmy Jabr.* I hope he is still there to read these lines which should be presented at his honor. The man came to see my work. After attending three periods, he asked me to sit for a while. He said, "Ustaz/Ahmed! Iam sorry to say that your performance was not that good!!! You were not teaching the language. You were actually lecturing them." I was stunned. Then I tried to defend myself and told the man that I was doing the best to show him all my craftsmanship in teaching. I expressed my dissatisfaction with his frustrating comments and I told him that it was unfair assessment to my work. He kept silent for a while and continued, "But let me tell you something; your English is very good. You have full presence in the classroom and your classroom management is fine. Let me tell you something about conducting a language lesson. You need to follow these three easy steps:

- Presentation: Present the subject to them in few words and in less than five minutes then...

- Practice: Let them practice the language, as the classroom is the only environment in which your students are exposed to semi real language situation. Give them all the time in classroom to allow them practice by making dialogues and doing much speaking, then ...

- Application: Then you have the back feed by making them apply the lesson by doing some drills as home assignments.

I thought I learned the whole tricks. I thanked the man. He volunteered to make some model teaching for me. He took my preparation book and came next day to do the teaching by himself in my three classes. First, we got into Grade 2. I told him that those students were (...). He said, " No. Ustaz/Ahmed, these boys are not (.....). It is the teacher who is the big (...)!!!". Oh!!! I felt embarrassed. I could not utter any more words. We got into the classroom. He began teaching. Most of the work was done by the boys. The boy would just sit down to grasp his breath, but he would soon have to stand up again to answer a shooting question. He kept them busy all the time. I could not believe that, those were really my own same (...) students as I had described them. They did very well and almost everyone participated in the class. It was marvelous. The same was done with the other two classes. I could not imagine that those people were really so brilliant-so gifted. He revised the alphabet with grade (1). He used many colored chalks. The board was something like color festival. He gave the children too much freedom to move inside the classroom. When I talked about what seemed to me as sort of chaos in the classroom, he said that kids would learn better through games and competition.

That day I realized that teachers were/are responsible for everything as Ustaz/Fahmy put it by saying that, "...you have to realize that behind any failure student, there must have been a failure teacher. Do you want to be a failure teacher, Ustaz Ahmed?" I said, "NO". It was the last time I saw the man. He did not pay me any more visits because as he said I would need no more advice. It was me who was to go to him in his office, instead. I used to go there frequently to talk to him and seek his advice. He was a wonderful teacher and supervisor. He made me love teaching as a helping 
profession. I found that to help young people achieve mental and physical growth is a wonderful job, especially when you are sure that those young men and women would be able to use those small machines in their heads effectively, to solve their life problems, when they leave school. From that moment I realized the important role of the language supervisor in providing teachers with the core knowledge in the area of language pedagogy, as well as enhancing the teachers' performance in their classrooms.

\section{B. Building Trust}

Supervision is about building working relationships with employees. Building a trusting relationship takes time. But when supervisor and employee trust one another, both of their thoughts and efforts can be applied to each situation. The likelihood of time-wasting conflicts is reduced. The supervisor has to trust the employee to get assigned tasks done in a satisfactorily manner. The employee needs to be able to trust the supervisor to back him fairly. missouribusiness.net . So the supervisor and supervisees both have to exchange positive feelings and attitudes for the benefit of their organization and the development of work. But the relation between supervisors and supervisees becomes complex when it comes to evaluation and judgments. The language supervisor has to make judgments about the performance of teachers. Assessment is one of the most challenging aspects of supervision. It should be much more in-depth than a simple judgment. If evaluation is carried out fairly we would expect constructive feedback from supervisees. Constructive feedback is a powerful tool to reinforce desired behavior because everyone likes to receive positive feedback on work well done. Good supervisors provide training and development for their employees and are glad to make the investment in refining employee skills. (missouribusiness.net). Through the feedback we would be able to judge the needs of our supervisees and provide them with suitable training and development opportunities that enable them to do their teaching.

\section{FOREIGN LANGUAGES EDUCATION}

It is quite evident that, one of the most important features of our modern time is the work nearly everyone does now; needs some interface with technology. If an organization embraces technology and has provided training for teachers in using that technology effectively, a great progress in pedagogical aspect will spread everywhere and benefit every learner. As mentioned before, that people all over the globe now find proficiency in foreign language of vital role in the development of their communities, in such a challenging growing economy. Language is the vehicle of thoughts and feelings. It is also the means, through which human communities were and still are able to establish warm contact and exchange feelings and ideas with mutual understanding. Through language man was able to set down this bulk of literature, which saved and conveyed the human heritage from one generation to another. Language was and still is the means of handling our daily life needs. Through language we can exchange commodities and services to satisfy our human physical, psychological and spiritual needs.

Governments and individual persons realized this language role; therefore language education has flourished as a social activity and as an economic tool as well. In this respect, as HişMANOĞLU (2010), put it English Language Teaching (ELT) has its own progress and is highly demanding due to several reasons, which implies that English language teachers are to keep up with the novel innovations and recent changes in this field. And as cited in (Bailey, Curtis and Nunan, 2001), staying abreast of the rapidly evolving field of ELT is a valid reason for participating in professional development. In the same vein, Pachier and Field (1997) propose that being an effective foreign language teacher requires a commitment to keep up with the developments in the field and a willingness to engage in continuous professional development. Furthermore, Çoşkuner (2001) argues that English language teachers should be able to satisfy the expectations of regularly increasing number of students by using up-to-date teaching methodologies performed adeptly with dedication and enthusiasm.

To achieve this purpose, HIŞMANOĞLU:(2010) says;[teachers] should be concerned with recent knowledge and comprehend many factors and variables that control and govern the learning and teaching in the classroom context. To maintain ongoing professional development, English language teachers must get involved in many professional activities to build up their own self-development strategies either individually or collaboratively. Peer-coaching, study groups, action research, mentoring, teaching portfolios, team teaching, and in-service training are some of the effective professional development strategies. But Clark (1992, p.81) believes that professional development is basically 'a solitary journey'; however, almost all teachers need assistance and support during that journey from colleagues or supervisors to enhance their own development, by which they can gain an inside perspective on other teachers' experiences and raise their awareness via reflecting on their own situation. At this point, Bailey et.al (2001) note that working in isolation holds teachers back and subjective experience shared with no one cannot contribute to their development, but through the quality collaboration, teachers have chance to escape from subjectivity and draw some conclusions regarding their experiences and opinions. HIŞMANOĞLU:(2011) concludes that educational supervision, as a cooperative problem-solving process, can be regarded as a key concept in English language teachers' professional development. Language supervision is an important issue. It has been tackled by many educationists such Wallace (1991), Ur (1996), Freeman and Johnson (1998), Richards and Farrell (2005) who all pointed to the impact of supervision on developing language teachers' skills. 
Foreign language teaching provides the national budgets of some countries like America, Britain, France and Spain with huge income, as the languages of these people are of great importance in this modern time in the exchange of thoughts, feelings, and services and as means of handling trade activities, and above all modern advanced technologies. Most people got independence from their old colonizers but they are still tied up to them through language and culture. Many people in Africa, South America and some parts of Asia still adopt their old colonizers' languages and cultures in their independent states. Some of these states have even given the old colonizer's language social status as lingua franca, among its people, as it is the case in India, where English is given official status, as the language in the government offices and the language of education in higher institutes.

\section{A. The Need for Language Education}

People need to learn a second language because of globalization that urges inevitable connections among nations, states and organizations. There is a huge need for learning foreign language or be multilingual. The uses of common languages are in areas such as; in trade, tourism international relations between governments, technology, media and science. (en.wikipedia). The foreign language education is not the concern of developing countries only but it is the concern of all. So it is not strange that many countries such as Japan create education policies to teach at least one foreign language in primary and secondary school level. However, some countries such as India, Singapore, Malaysia and Philippines make a second official language in their governing system. The Chinese people are giving enormous importance to foreign language learning especially learning English Language. Spanish is another widely learned second language, having a slightly higher figure than English at 332,000,000 speakers. (en.wikipedia.org). The developing and the least developed countries are in much need than others because they are lacking behind in the possession of knowledge in almost every field, from sciences and technologies to arts and humanities. The foreign language teacher with the aid of the language supervisor may be practically much more needed professions than even physicians or engineers in these developing countries. As through the efforts of these teachers, highly qualified personnel in those fields can gain the knowledge, through their own personal effort by reading in the foreign language, or by benefiting from the translations done by these language factions in transferring knowledge from its original resources to the target languages.

\section{B. Major Foreign Languages outside their Home}

European and other languages are dominant outside their homes. English, Spanish, Arabic, Protégées are spoken all over the world as shown in the table below.

\begin{tabular}{|l|l|l|l|l|}
\hline English & Spanish & Arabic & Portuguese & French \\
\hline 594.000 .000 & 311.000 .000 & 260.00 .000 & 131.000 .000 & 161.000 .000 \\
\hline
\end{tabular}

The French language is spoken by 51.000 .000 as mother tongue in France and by 128.000 .000 people as first language in about 53 countries round the world; 23 countries are in Africa according to Statistics of 1999. The French is making influence after the Françoise Mitrane's announcement in the Dakar Francophone Summit in May 1989, where he declared, that France would drop all its debts of 16 billion Francs, against 35 African countries, if those countries give the French language superiority on other languages in government offices and in education. The English language is spoken by 55 million people in the United Kingdom as mother tongue, while it is spoken by 508 million people in 104 countries, as first or second language round the world. It is spoken in 22 countries in Africa. English is making its way in the world, as it is the language of the computer, internet communication and businesses round the world. Portuguese is spoken in the former Portuguese colonies of Angola, Cape Verde, Guinea-Bissau, Mozambique, and São Tomé and Príncipe. It is spoken by around 170 - 210 million people as mother tongue in the world, while it is spoken by 9.9 million people in the motherland Portugal and 151 million people in Brazil. The Policy of Portugal to offer full right of citizenship to the speakers of Portuguese language produced positive results to increase the number of speakers of this language. (Encarta.encyclopedia)

\section{The Political, Cultural and Socioeconomic Role of International Language}

TOEFL \& ILETs are two famous language examinations taken by millions of people all over the world for educational and cultural purposes. These two examinations are a must for everyone who wants to admit to a higher educational institute in America, Canada, Britain and Australia and many other countries. The results are also used for immigration purposes to some of these countries. These two tests are used as yardsticks to determine the degree of language proficiency of a newcomer or immigrant to those inviting communities such as America, Britain, Canada and Australia. But the results may also be used as political or socioeconomics tools with hidden government agendas. See (Shohamy: 2006), (Siddiek:2004)

TOFEL: This test is the most widely respected English-language test in the world, recognized by more than 7,500 colleges, universities and agencies in more than 130 countries. The ETS organization is the body that, "develops, administers and scores more than 50 million assessment tests annually in more than 180 countries, at more than 9,000 locations worldwide. In addition to assessments, it conducts educational research, analysis and policy studies and develops a variety of customized services and products for teacher certification." The ETS provides its services to 
English language learning and elementary, secondary and postsecondary education. More than 2,500 people are carrying out this job worldwide in nine offices. For more details you can see (ets.orgs)

IElTs: is the English copy of TOEFL as it is one of Britain big business and supplies the British budget with very big income. IELTS is the world's proven English test. Over 1.4 million candidates take the test each year to start their journeys into international education and employment. IELTS is the International English Language Testing System, the world's proven English language test. IELTS was one of the pioneers of four skills English language testing over 21 years ago, and continues to set the standard for English language testing today. Close to 6000 organizations and more than 1.4 million test takers around the world. IELTS is jointly managed by British Council, IDP: IELTS Australia and the University of Cambridge ESOL Examinations (Cambridge ESOL) through more than 500 locations in 130 countries. It is recognized by more than 6000 institutions in over 135 countries. (ielts.org.com)

\section{Foreign Language Education in Europe}

European Commission's White Paper "Teaching and learning - Towards the learning society", stated that "upon completing initial training, everyone should be proficient in two Community foreign languages". The Lisbon Summit of 2000 defined languages as one of the five key skills. In fact, even in 1974, at least one foreign language was compulsory in all but two European member states Ireland and the United Kingdom (apart from Scotland). (wn.com/Certificate). By 1998 nearly all pupils in Europe studied at least one foreign language as part of their compulsory education, the only exception being the Republic of Ireland, where primary and secondary schoolchildren learn both Irish and English, but neither is considered a foreign language although a third European language is also taught. Pupils in upper secondary education learn at least two foreign languages in Belgium's Flemish community, France, Denmark, Netherlands, Germany, Luxembourg, Finland, Sweden, Switzerland, Greece, Cyprus, Estonia, Latvia, Lithuania, Poland, Romania, Serbia, Slovenia and Slovakia. On average in Europe, at the start of foreign language teaching, pupils have lessons for three to four hours a week. Compulsory lessons in a foreign language normally start at the end of primary school or the start of secondary school. In Luxembourg, Norway, Italy and Malta, however, the first foreign language starts at age six, in Sweden at age seven and in Belgium's Flemish community at age 10. About half of the EU's primary school pupils learn a foreign language.

\section{E. Language Education in the United States}

In most school systems, foreign language is taken in high school, with many schools requiring one to three years of foreign language in order to graduate. In some school systems, foreign language is also taught during middle school, and recently, many elementary schools have begun teaching foreign languages as well. However, foreign language immersion programs are growing in popularity, making it possible for elementary school children to begin serious development of a second language. In late 2009 the Center for Applied Linguistics completed an extensive survey documenting foreign language study in the United States. The most popular language is Spanish, due to the large number of recent Spanish-speaking immigrants to the United States (Spanish in the United States). According to this survey, in $200888 \%$ of language programs in elementary schools taught Spanish, compared to $93 \%$ in secondary schools. Other languages taught in U.S. high schools in 2008, in descending order of frequency, were French, German, Latin, Mandarin Chinese, American Sign Language, Italian, and Japanese. During the Cold War, the United States government pushed for Russian education, and some schools still maintain their Russian. (examiner.com.) A bill in the Congress dramatically expanded Mandarin Chinese language classes for American students. The measure, the U.S.China Language Engagement Act, would award competitive grants to schools to "establish, expand or improve" Chinese language and cultural classes. It also expanded technology options to help American schools establish "virtual connections" with schools in China. While an estimated 200 million Chinese school children are studying our language and culture, less than 50,000 American elementary and secondary students are studying Chinese, seeking to improve our competitive edge and relationship with China." (examiner.com) Foreign languages are needed in USA for national security as national security experts have said that the U.S. has a shortage of qualified "critical language" speakers specifically Mandarin and Arabic. Both the CIA and FBI regularly advertise positions with their agencies for Americans who possess some Chinese ability. The 9/11 Commission Report criticized the weak foreign language capabilities of the government's national security agencies.

On the campaign trail, then-candidate Barack Obama stressed that foreign language instruction should be expanded in American schools. "I don't speak a foreign language. It's embarrassing," he said. "It's embarrassing when Europeans come over here, they all speak English, they speak French, and they speak German. And then we go over to Europe and all we can say is merci beaucoup, right?" (ibid)

\section{F. UNESCO's Work on Languages and Multilingualism}

According to UNESCO, languages are humankind's principle tools for interacting and for expressing ideas, emotions, knowledge, memories and values. Languages are also primary vehicles of cultural expressions and intangible cultural heritage, essential to the identity of individuals and groups. Safeguarding endangered languages is thus a crucial task in maintaining cultural diversity worldwide. UNESCO's work on languages and multilingualism takes many forms building capacity, research and analysis, raising awareness, supporting projects, developing networks, disseminating information. (unesco.org). As these activities are interdisciplinary in nature, they are spread throughout UNESCO's five 
programme areas, each one addressing particular aspects of language issues: Such as the cultural diversity, dialogue and exchange, protecting cultural heritage, monitoring languages policy, language endangerment and translation flows and safeguarding endangered languages, particularly through support to professional in the field of translations and publications. The activities of the Education Sector concern promoting inclusion in education and quality learning enhancement by supporting bilingual education, especially the use of mother-tongues, at all levels of the education system and in formal and non-formal settings; paying special attention to policy advice, teacher training, the development of textbooks and learning materials and collecting and disseminating good practice in bilingual and multilingual education and literacy. (unesco.org) It is evident that we in the developing countries do agree with the international organization's mission, that there is a growing awareness that languages play a vital role in development, in ensuring cultural diversity and intercultural dialogue, but also in attaining quality education for all and strengthening cooperation, in building inclusive knowledge societies and preserving cultural heritage, and in mobilizing political will for applying the benefits of science and technology to sustainable development. But how is this bright picture reflected in reality? This is something we will go over somewhere on the next pages of the survey.

\section{G. Language Education in Developing Countries}

The UNESCO believes that the quality of learning is and must be at the heart of everybody. All stakeholders teachers and students, parents and community members, health workers and local government officials - should work together to develop environments conducive to learning. To offer education of good quality, educational institutions and programmes should be adequately and equitably resourced, with the core requirements of safe, environmentally friendly and easily accessible facilities; well motivated and professionally competent teachers; and books, other learning materials and technologies that are context specific, cost effective and available to all learners. (www.unesco.org) The organization also believes that teachers are essential players in promoting quality education, whether in schools or in more flexible community-based programmes; they are advocates for, and catalysts of, change. No education reform is likely to succeed without the active participation and ownership of teachers. UNSECOC sees teachers at all levels of the education system should be respected and adequately remunerated; have access to training and ongoing professional development and support, including through open and distance learning; and be able to participate, locally and nationally, in decisions affecting their professional lives and teaching environments. Teachers must also accept their professional responsibilities and be accountable to both learners and communities.

Theoretically, this is all perfect but in reality little is done to raise the standard of education in developing countries. The Dakar declaration about primary education for school age boys and girls promised the developing nations with (dreams) to promote education in their countries for young men and women. The World Education Forum (26-28 April 2000, Dakar)adopted the Dakar Framework for Action, Education for All), that all children must have the opportunity to fulfill their right to quality education in schools or alternative programmes at whatever level of education is considered 'basic'. All states must fulfill their obligation to offer free and compulsory primary education in accordance with the United Nations Convention on the Rights of the Child and other international commitments. The international agreement on the 2015 target date for achieving Universal Primary Education (UPE) in all countries will require commitment and political will from all levels of government. (unesdoc.unesco.org). So it was expected that by 2015 that every child should have a place at school and be able to read. But it seems that all those dreams were deferred. In my country Sudan as an example- the rate of primary school enrollment among school age children is very low as somewhere $90 \%$ of children at school age do not find places in primary school education, especially in rural areas. (www.alwatansudan). The case is applicable to many other African countries. But we can trace some bright attempts where real efforts are exerted to promote children education.

India: Some developing countries like India have made big progress in primary education. The Indian government promised school children with access to computer networks even in the very remote villages in the Himalaya. The Indian government was planning to provide cheap laptop machines to young generation. The buzz and hype surrounding the Indian Education Ministry's breathless announcement ...that it would be unveiling a \$10 laptop aimed at the poor fizzled out like a wet firecracker. (foxnews.com/). Language education in India witnesses great development as English has official status as the second language in the country as lingua franca among the peoples of India. We can easily notice the linguistic performance of Indian experts outside India, where Indians efficiently use English, although with heavy Indian accent which sometimes make it difficult to understand the speaker. Nevertheless, the Indian are holding great position in education, finance, banks and private sector in the Gulf region as highly qualified personal in computer, accounting and management. For further details on language see: (www.languageinindia.com)

Saudi Arabia: This is another example, where the education budget has come to $26 \%$ of the national GNP during this fiscal year 2011/2012. There are big projects under construction, as about ten new regional universities were launched and thousands of young Saudis are sent abroad in what is known as King Abdulla's Project for Scholarship. This programme would qualify thousands of Saudi young men and women to get higher degrees in almost every field. Special attention is given to language education especially the English language, where thousands of Saudis leave to USA, Canada, Australia, New Zealand and Britain to improve their language skills or proceed for further degrees. Saudi Arabia is a monolingual country where the population speaks only Arabic as mother tongue with very little variations of accents in the different regions. English is taught as a foreign language from the junior secondary school, at the age of 12, but new orientation is there to start teaching the language from age 6 in the primary education. English 
is the working language of many leading industrial corporations such as Aramco, Sabic and other major leading educational institutes as King Fahad University for Petroleum and Minerals, in addition to the new renowned King Abdullah University in the Western Region in Tool, an $80 \mathrm{KM}$ drive from Jeddah.

The need for foreign languages in Saudi Arabia is very demanding as the country is the Qibla of more than one billion Muslims who practice their Islamic rituals every day facing the Kaaba in the Holly City of Makkah. In addition to some other millions who frequently come to Saudi Arabia to perform their Hajj or Omra every year. These millions of people need to exchange ideas, feelings and services either in their own languages or they have to shift to English as a practical media of communication. So we can see the importance of this language in this country. Young Saudis are supposed to be trained so as to help these Pilgrims in the airports, seaports, medical centers or in the Masha'ar in Mina and Arafat. English is also important as Saudi Arabia is the guest home for than 7 million expatriates who are participating in the big development projects in the Kingdom in almost every field, from industry to health services to education and other economic fields. These foreign experts use English to communicate with their employers especially in private companies and banks.

\section{H. Foreign Language Education in Africa}

According to Obanya (2010), most African countries (referring specifically to Africa South of the Sahara) were colonized from about the middle of the 19th century to the 1960s. The only notable exception to this general trend is Ethiopia, but the fact that the country was occupied in the 1930s by the Italians also meant that it cannot completely escape from the colonial stamp. That each colonial power imposed its own language on the African countries it colonized is a well known fact. Obanya (2010) notices that the imperial educational and colonial policies often determined the level of entrenchment of the colonial language, and the extent to which indigenous languages were tolerated and consciously promoted in the educational system. In general, the colonial languages policy in education in Africa followed the colonizers' policy, so as countries colonized by the French taught the French language at all levels, and from the first day in school, while countries colonized by the Spanish and the Portuguese had a practice very similar to that of the French. However, as Obanya said, 'the countries colonized by the British taught English at all levels, but always made sure that the first years of formal education were conducted in the first language of learners or in the language of their immediate environment. But countries colonized by the Germans, while seriously promoting the German language, also gave prominence to indigenous languages in the early years of schooling.' (fafunwafoundation/id1.html)

\section{Foreign Language Education in Sudan}

The Sudan was once under the British rule up to 1956, when it announced independence from within the parliament. The English language was the medium of handling work in the government offices and in education in the secondary school, where all subjects were taught in English except, of course, Arabic and Islamic Religion subjects. English was also the medium of instructions at higher education in Gordon Memorial College which was established in 1902 to provide higher education in the Sudan. The teaching of English was encouraged by the government and it was also the interest of individuals, as mastering the language was an authorization for getting a promising job in the government offices. After independence, Sudan joined the Organization of the Arab Union and adopted Pro-Arab policy where Arabic began to find its way in education institution and government offices. In 1989 a huge movement of Arabization took place where the ruling regime finally took the side of the Arabs and set a policy of Arabization and Islamization of the country. Arabic then was nominated as the language of the government and education. This resulted in an immediate drop of standards in foreign language education -English and French- and the situation was worsening every time and then. English is now taught from grade 6 primary and three books are taught here. Then another three textbooks are taught at the secondary school 3 periods per week in comparison to 8 periods per week in the past. The syllabus had been written in a hurry, so it seems it has not achieved positive goals as continues complaints from teachers about the poor performance of students in languages has not stopped. Teachers show great dissatisfaction with the syllabus and described it as poor, un-oriented and purposeless. And due to shortage of teachers; untrained teachers do the teaching of English as a school subject. The general achievement tests show low attainment in language competency and practically oral commutation is totally lacking, as the teachers are not alert with new teaching trends methodology or they lack the educational aids which can help facilitating the language teaching. See Siddiek (2009).

During my own teaching experience, I saw the supervisor several times. It was just a piece of luck, because I was working in one of the best private schools in the city with relatively good facilitates. But to my colleagues in the public schools no supervision or even (inspection) visits were paid. We can conclude from this that the picture of foreign language education in Sudan is not that bright and the role of the language teacher and language supervisor is almost lacking.

\section{MODERN EDUCATIONAL SUPERVISION}

\section{A. Characteristics of Modem Educational Supervision}

Bailey: (2006), sees the modern educational supervision is characterized as follows: 
- It is a technical process which aims to improve teaching and learning through the care, guidance and simulation of continued development for not only teachers but also any other person having an impact on the educational context.

- It is a consultation process, based on respect for the opinion of teachers who are mainly affected by the work of supervision.

- It is a collaborative process in different stages since it welcomes various views that represent the proper relationship between the supervisor and the teacher so as to address the educational problems and find appropriate solutions.

- It is an academic process which encourages research and experimentation whose results can be used to improve setting and achieving clear, observable and measurable objectives in the educational setting.

- It is a leadership process which requires the supervisor to have the ability to coordinate teachers' efforts by aiming to achieve the teaching objectives.

- It is a humanitarian process in which the supervisors recognize the value of individuals as human being so that they can build a mutual trust between themselves and the teachers and know the exact and varying capacities of each teacher they deal with.

\section{B. Historical Perspectives of Language Supervision}

Some years back the departments of education used to judge the quality of teaching by examining teachers' performance though what was to be known as (inspection visit). The department of inspection used to hire a group of inspectors with relative experience in school disciplines such as languages, mathematics, sciences or social sciences. Inspectors of education used to pay sudden visits to examine the students' achievements in schools subjects; and on the light of that visit they formed their decisions and judgments on the teachers' performance. Then the teacher would either be promoted, dismissed or if he was lucky enough, he would be moved to another place. But in the last thirtysomething years, education researches have come to new inventions. New terminology was employed due to modifications in the core message of scholastic inspection, which was turned to be technical orientation rather than inspection tours. The process was changed into a tool aimed to help the teacher in his/her work and develop his/her performance and cared for the growth of teachers' knowledge and skills rather than just seeking their faults and weaknesses. Educational supervision was then seen as an effort aimed at helping teachers to grow in the profession and develop efficiency in their teaching performance. Then gradually the whole process was directed towards the growth of the learners' - based concerns. The development of the whole education process became the ultimate of education. From here we have come to see the new concept of what is known today as educational supervision, a new term with new features and contents.

Educational supervision as I see it is a process of social human interaction aimed at raising the level of teacher professionalism to the highest possible degree in order to raise educational adequacy and achieve ultimate pedagogical goals, as those embedded in the taxonomies of education such as Bloom's Taxonomy of Educational Objectives. The educational supervision - therefore - is to be seen as a cooperative democratic process composed of two partners: the educational supervisor as leader and teacher as supervisee. The process aimed at exploring and understanding the objectives of education and helping the teacher to assimilate the goals and seriously work towards achieving them. This definition represents a quality leap very far from the old concept and practice, because it ance canceled the superiority of old inspectors upon teachers and stopped harming them by what was seemed to be only hunting teachers' mistakes. This new practice has improved the contact between the supervisors and supervisees into warm human interaction based on natural mutual respect.

The definition has also gone beyond the technical guidance as from just being just a follow-up of teachers in schools, to correct the practice on experience and advice, drawn from outside the school, to link technical guidance with the distinction of the supervisor in one specific educational subject matter. This new concept of educational supervision has removed the psychological barrier between the supervisee teacher and the educational supervisor as it considered both sides as cooperating partners, together in one single process to attain shared objectives. Thus, the very end of educational supervision is the development of the educational process, and not the teacher in his helplessness or vulnerability in the presence of the educational supervisor.

Educational supervision was also defined as a process of leading a cooperative teaching organization, with all the elements of the curriculum, educational aids and methods of teaching, in educational environment with teacher and pupil. The aim was to study the affecting factors in such situation and make assessment of the work to improve learning in the organization, in order to achieve better the goals of learning and teaching. Educational Supervision is also defined as including all the ongoing cooperative educational activities carried out by supervisors, educators, school administrators, peers and teachers themselves, in order to improve the skills of teachers and achieve educational development, which all leads to achieving the objectives of the educational process - that is composed of the teaching and the learning.

\section{Development of Concepts of Supervision}

There were two major powers affected the rapid growth of educational supervision. The first represented the outcome of the socio-cultural factors, such as population growth, the change of the community around the school, and the 
attention given to the quality of education. The second power represented the modern theories that have emerged in this area; such as the new theories and studies in behavioral sciences which have opened up new horizons of thinking in the nature of the objectives and practices of educational supervision, and the role of educational supervisor, his status and the extent of his authority in his community. Developments in pedagogical theories and educational technology have direct effect on the adoption of new conception and functions of language supervisor. The concept of educational supervision has developed from that one visit type- as it was used to be- which was not sufficient for the inspector to form a fair idea about the performance of his supervisee. That one visit would not enable him to judge and evaluate the teacher in term of the outcome of his work, as reflected in the responses of his students. These responses were limited to a number of questions addressed to them from their school subject in this one visit time. So the one period visit paid by the supervisor to the teacher in his classroom, was not enough also to enable him realize the adequacy of the teacher's performance and the degree of his awareness of the purpose and practice of the methods of the subject, to raise interest in students in and take into account their abilities, need and their preparedness. So this made educators move from knowledge to the development activities of thinking. Here the role of educational supervisor in the evaluation of curriculum development and its contribution in the training of teachers is highlighted; where he would move from evaluating the knowledge of the teacher to establishing values in the teacher. This required the supervisor to immerse himself deeply in this field to help teachers overcome problems which they face while carrying out their duties, by focusing and addressing the students' mind. The basic principles of education consider education as an integrated process. So the separation between the tasks of supervisors as a specialist in limited topic of study, confirms the move away from paying attention to the conditions of the school, and the other administrative aspects; which are considered as important integrating factors in the success of the whole education process. The teacher at the school does not work in a vacuum, but he sets off from the educational system in relation to other social, economic and religious policy. So the language educational supervisor cannot provide the educational support and learning unless he is positively affected by the educational system in general and the general surrounding environment conductive to teaching and learning.

Responsibilities of Language supervisors: First, the conditioning and reconditioning of new teachers for their work: Teachers are usually trained in teacher training colleges and assigned to carry out field work as requirements their study. But due to problems facing them when engaged in actual work in schools where they are recruited to work, here comes the role of the educational supervisor in collaboration with the school administration to shoulder the responsibility of preparing these new newcomers for their work.

Second: sessions for teachers during the service: The educational supervisor is always in the field so he is alert of the problems faced by teachers, and the deficiencies in the educational services provided to students. He has to see these problems as evidences of good learning and positive growth of the supervisees. On the light of this, language educational supervisors in collaborative effort suggest some courses that address the weaknesses which they observe in their supervisees. Through their keen observations they would be able to judge the practical needs of their supervisees. Accordingly, language supervisors can help these teachers by many tricks such as: holding session on computer literacy, cooperative teaching, workshop in educational evaluation and measurement to help teachers improve their testing skills, workshops on implementation of local materials from the local environment as educational tools. Language supervisors can also hold session in helping language teachers to develop interests in students in outdoor activities and engagements such as visiting educational institutes or places where they can safely mingle with foreigners to listen and practice the language in natural situations. The language supervisor can be of great help to his supervisees to enable them to have easy access to library resources to help develop their learning and study skills. But the most places where the language supervisor is badly needed, is to help providing his supervisees with the latest trends in language teaching methods and approaches, as well as explaining to them the latest theories in the field of pedagogy, educational psychology and trends in the philosophy of education which are all supposed to be fields of shared concern.

Meeting with language teachers: These meetings should be at the beginning of the new academic year, where the language educational supervisor can chooses one aspect of language teaching, to discuss in respect to the curriculum and the textbooks to see its adequacy on teacher's guide. The fruits of this meeting will raise the awareness of teachers to some important aspects of the curriculum and they make them think of the time factor to deal with this aspect from the beginning. The meeting can also take place after examinations in a form of workshop in which the supervisor can make analysis of previous examinations with his supervisees.

Curriculum Development; The process of developing the syllabus should not remain the mission of the general administration of education alone- although this is the place which is responsible of tailoring and developing curriculum, as action that is individually carried out by this administration, but curriculum development should come as a result of developments contributed to by joint efforts of the language educational supervisors as leaders in the fields, and keen collaboration with teachers, who practically carry out the directives of the curriculum from mere programmes into practice with their students in school.

Classroom models: The success of the teacher in his classroom is mainly affected by his ability to manage his classroom, so it is not sufficient for the teacher to only master his subject matter. It is also not enough to adopt specific approaches of teaching but using sophisticated educational tools is a must. The supervisor can introduce himself as a model by showing his craftsmanship and his experiences of teaching by carrying out practical teaching tasks before the teacher in the classroom. 
Selection and recruitment of teachers: The language supervisor through his visits could recognize the teachers who can be taken as models for their peers. He could assemble all his staff in a meeting at the end of each term to discuss some teaching strategies which one specific teacher followed in his teaching. They can also help by suggesting new approaches if the old ones did not work. The language supervisor as a link between the administration and the teacher in the field is in a position to allow him effectively picture the situation and know the needs of each school for specific teachers, in one specific language aspect; thus he can recommend the selection of teachers who are suitable for the work or the specific school needs.

Encouraging teachers to go beyond the textbooks: Most of the time teachers tend to literally keep to the textbook as they would believe that these textbooks materials are well selected teaching materials. They think that this would help them avoid committing mistakes, but they should understand that these textbooks are just models that represent the overall requirements of the syllabus, but they do not entirely reflect the whole truth about it. So if the teacher literally keeps to the textbook and if he does not find the one who helps him about the importance of the additional sources of learning outside the syllabus, this behavior would make the teacher close down one of the widest windows for acquiring knowledge, far away from textbooks. In this case the supervisor has to tell the teachers about the diversity and availability of other sources of education from within their learners' local environment.

Examinations: Examinations awareness should be one of the most important tasks for the active supervisor as through examinations he will be able to judge the success of the teaching strategies adopted by his supervisees. He can also be able to evaluate the success of the syllabus from the feedback of the examinations' results exams and determine the attainment of the national, local or personal educational objectives of the course. He can also infer the usefulness and the credibility of the whole educational philosophy of the country through the success of the whole educational process embedded in the performance of both teachers and students. To create examination awareness, supervisors have to hold meetings and sessions for training their supervisees about examination literacy. Teachers should know first the importance of examinations as high -stake tasks on which very critical decisions are made to determine the fate of examinees. They should know the types of examinations and be aware of key concepts and terms such as reliability, validity, comprehensives and washback and how to apply these concepts in practice.

\section{Mechanism OF SUPERVISION}

Classroom visit: In this type of education supervision, the language supervisor usually pays a direct visit to the teacher in his classroom. It was the oldest way of supervision. This kind of visit might help the supervisor to form a fair idea about the teaching and the learning processes, as well as inspecting the educational environments under which the education process is run. He might also be able to see the suitability of educational aids. Many education departments depend on the supervisors visit to help the organization plan its general educational policies.

Sudden visit: This is an undeclared visit but it is no longer acceptable now. This type of visit comes as a result of the language supervisor receiving frequent reports from school authorities about a poor performance of one specific teacher. In this case the language supervisor will pay a sudden visit to investigate the case and make certain judgments on it. This kind of visit is considered as an inspecting visit and not for teacher's orientation or instructions, so it is not expected to serve directly the teacher nor the education process.

Programmed visit: It is expected to serve two objectives: to assess the teacher's performance and serve attaining the goals of the supervision department in the educational organization which can be the ministry of education in this case.

$A$ visit required by the headmaster: The school director may need the technical and academic advice of the supervisor, so he might ask him to pay a visit to the school vicinity to solve such pending problems.

Exchanging viewpoints between the language supervisor and the teacher: The interaction between the language supervisor and his supervisees is the core objective of his visits to school. This exchange of ideas has an enormous psychological effect on the teacher to modify his behavior and enhance his knowledge and education. This will be reflected as a positive incentive to the teacher and helps in the development of his students' achievement in the long run.

Practical Model of Teaching: In my long teaching experience Iam still indebted to the first visit of my English language supervisor. The man took the burden of showing me how he was doing teaching. He taught three different classes. It was marvelous and most the time the students were to do the whole of the work practicing the language in the classroom. I felt that he was able to elicit the right performance and achieve the right objectives of the lesson, as he was able to establish an authenticated learning environment for the kids. That was a modeling experience through which I was able to modify my teaching practice and check the efficiency of my performance from the immediate feedback of my students. Some teachers may doubt the probability of the implementation of innovative ideas in teaching. So this kind of modeling practice can give them confidence and encouragement, as well as telling them the truth, that almost all educational objectives can be applied and interpreted into real learning situations and can be fully assimilated by the learner, if they are well handled. Innovation is one important feature of creative teaching. We have to tell teachers not to stick to one specific approach of teaching. S/he can try many tricks to make oneself clear to students. We also need to tell teachers that the textbook - although it is an effort of good men and women- but it is still a human effort to which $\mathrm{s} /$ he can add some modifications gained from their knowledge and from their own personal teaching experiences.

Peers in Classroom: Language supervisors should spare no efforts to help teachers do the job, but they cannot do all of it by themselves. They may miss some points or ideas. Teachers can fill the gap by paying exchangeable visits to 
their peers in class. This event would be a good moment of exchanging experience with each other. Teacher-to-teacher visit would be of little tension as teachers share the same worries and have the same attitudes. This would definitely reduce the degree of tension, worry and fear because both teachers feel the naturalness of the situation and the normalness of the environment in which the whole teaching is done.

Refreshing Sessions: The language supervisor is responsible for satisfying the practical needs of teachers in qualifying them by developing their teaching skills. So on the light of his educational visits to teachers; he would always be in a position to judge what these teachers would practically need to develop their performance in the classroom. The language supervisor through these tours would be able to see the pinpoints of weakness in his staff. He would discover that some teachers lacked behind and not up-to-date in their knowledge and skills. They did not know how to follow the new innovations in educational development. This exploration requires an immediate response from the language supervisor to make refreshing sessions to provide teachers with new development in the field of language teaching, developmental psychology and betterment of school environment in general.

Educational Conferences: Educational conferences are lively events where experts in specific trade would gather in one place to exchange new ideas, innovations and data in their specialty filed. Definitely this kind of gathering is not always accessible to everybody in the field of education. And that, almost the majority of teachers may not be lucky enough to witness such gatherings. The language supervisor may suffice his supervisees by attending such meetings and convey the new ideas to this audience. The supervisor through his official position is always in access to the resources of education and decisions, so his envelopment and participation in such meetings would be of great help to his supervisees.

\section{CONCLUSION}

The position of a foreign language supervisor offers advantages above and beyond that of a generalist teacher. The language supervisor possesses specialized knowledge of language acquisition, materials, content, methodology, second language learning styles, and best practice knowledge. Content specific knowledge can help to articulate a program knowledgeably, provide specific information, ideas, methodology, and techniques to maintain and improve language programs.(ncssfl.org/paper). So the role of the modern language supervisor is not to impart his expertise to supervisees but his role is to make change in the whole education process as he is the first man in the education arena. He is the middle ring between the organization at the administrative level and the teachers at the technical and practical level in the field. Language supervisors can make considerable positive change in his supervisees, because he posses the core knowledge of the subject and the craftsmanship \& the know-how to keep sustainable teaching and learning situations in their educational organization. The language supervisor as a specialist, can: -

- Provide leadership in the ongoing design and implementation of the foreign language program dealing with program, curriculum, and articulation.

- Work with teachers on improving methods, techniques, and skills through professional development for instructional improvement based on current research, trends in language teaching, and district needs.

- Stay knowledgeable about the development of foreign language learning materials by publishers and others, as well as supervising the selection and acquisition of appropriate textbooks, ancillary materials, and technology.

- Serve as a resource on effective foreign language instruction, national issues, and related legislation for all staff and the community.

- Stay abreast of trends and issues in foreign language education and brings innovation and renewal to instruction.

- Collaborate with teachers to promote instructional consistency and shared direction and with colleagues in other content areas on interdisciplinary curriculum and staff development.

- Stay actively involved in foreign language organizations and provides up-to-date knowledge to the district. For details see :(http ://www.ncssfl.org/papers/index.php?supervisor)

\section{ACKNOWLEDGEMENT}

This article is dedicated to my English Language Supervisor Ustaz/Fahmy Jabr of Egypt whose leadership put me on the track of this attractive \& charming profession.

\section{REFERENCES}

[1] Bailey, K. M. (2006). Language teacher supervision: A case-based approach. Cambridge: Cambridge University Press.

[2] Bailey, K.M., Curtis, A., \& Nunan, D. (2001). Pursuing professional development: The self as a source. Boston, M.A: Heinle \& Heinle.

[3] Clarke, D., \& Hollingsworth, H. (2002). Elaborating a model of teacher professional growth. Teaching \& Teacher Education, 18(8), 947-967.

[4] Clarke, A. (1995). Professional development in practicum settings: reflective practice under scrutiny. Teacher \& Teacher Education, 11(3), 243-261.

[5] Coşkuner, M. (2001). Turkish provincial state university teachers' perceptions of English language teaching as a career. Unpublished M.A thesis. Ankara: Bilkent University. 
[6] Freeman, D. (2001). Second language teacher education. In R. Carter \& D Nunan (Eds.). The Cambridge guide to teaching English to speakers of other languages. (pp. 72-79). Cambridge: Cambridge University Press.

[7] Freeman, D., \& Johnson, K. E. (1998). Reconceptualizing the knowledge base of language teacher education. TESOL Quarterly, 32(3), 397-417.

[8] HiŞMANOĞLU, Murat \& Sibel. (2011). [online]. At www.novitasroyal.org/Vol 4_1/hismanoglu.pdf

[9] Microsoft ${ }^{\circledR}$ Encarta® Reference Library 2003. ( ${ }^{\circledR}$ 1993-2002 Microsoft Corporation.

[10] Pachier, N., \& Field, K. (1997). Learning to teach modern languages in the secondary school.

[11] Shohamy, Elena.(2006). Language Policy: Hidden agendas and new approaches. First published 2006 by Routledge. 2 Park Square, Milton Park, Abingdon, Oxon OX14 4R

[12] Obanya, P. A. I.(2011). LANGUAGE EDUCATION IN AFRICA: LESSONS FOR AND FROM NIGERIA. http://fafunwafoundation.tripod.com/fafunwafoundation/id7.html. [online], retrieved on 26/3/2011

[13] Richards, J. C., \& Farrell, T.S.C. (2005). Professional development for language teachers. Cambridge: Cambridge University Press.

[14] Siddiek, Ahmed Gumaa. (2009). Assessment of the Sudan School Certificate English Examinations. Published by (www.lulu.com).UK.

[15] Ur, P. (1996). A Course in Language Teaching: Practice and Theory. Cambridge: Cambridge University Press.

[16] Wallace, M. J. (1991). Training foreign language teachers: A reflective approach. Cambridge: Cambridge University Press.

[17] http://www.missouribusiness.net/sbtdc/docs/supervisory_skills.asp. [online], retrieved in 30/03/2011

[18] http://www. en.wikipedia.org/wiki/Language education. [online], retrieved in 22/4/2011.

[19] http://www.ets.org/about/fast_facts. [online], retrieved in 22/4/2011

[20] http//:www.ielts.org/test_centre_search.aspx. [online].retrieved in 22/4/ 2011.

[21] http//:www.wn.com/Certificate_Supérieur_de_França. [online], retrieved in 22/4/2011

[22] http//: www.unesco.org/en/...and.../programmes-and-activities/.[online], retrieved in 25/4/2011

[23] http://www.unesco.org/images/0012/001211/121147e.pdf.[online], retrieved on 25/4/2011.

[24] http://www.alwatansudan.com/index.php?type=3\&id=14669. [online], retrieved in 25/4/ 2011

[25] http://www.foxnews.com/story/0,2933,487746,00. html. [online],retrieved on 25/4/2011

[26] http://www.languageinindia.com/feb2004/lucknowpaper.html.[online], retrieved in 25/4/2011

[27] http://www.ncssfl.org/papers/index.php?supervisor. [online], retrieved in 3/5/2011

Ahmed Gumaa Siddiek was born in Erahad-Sudan, in 1957. He got his BA in English with (MERIT) from Khartoum University in 1982, an MA in Translation from the Islamic Institute for Translation in Khartoum, an M.ED in (TEFL) from Juba University Sudan in 2001. Then he was awarded his Ph.D with (EXCELLENT) in (Language Testing)) in 2004 from Omdurman Islamic University - Sudan. Since then Dr. Siddiek has lectured in Sudanese and Saudi Universities. Dr. Siddiek has published articles in ELT journals in USA, UK and Canada. He also attended conferences and read papers in Harvard University, Purdue University, Ohio State University in USA. Schusltrap in Germany, and Ryerson University in Canada. Dr. Siddiek is the Author of: Assessment of the Sudan School Certificate English Examinations AND Language Challenges in Post War Sudan. Both books are available at amazon.net. Dr. Siddiek is a member of the editorial Board of (International Journal of English Linguistic in Canada). His major fields of interest are testing, translation \& language planning. Some of his articles appeared in the following journals:

- (English Language Teaching) CANADA http://www.ccsenet.org/journal/index.php/elt/issue/view/240

- (Asian Social Science) CANADA http://www.ccsenet.org/journal/index.php/ass/issue/view/294

- (International Education Studies) CANADA http://www.ccsenet.org/journal/index.php/ies/issue/view/231

- (European Journal of Social Sciences) UK http://www.eurojournals.com/ejss_16_4.htm

- (Research Journal of International Studies) UK http://www.eurojournals.com/RJIS_17.htm

- (International Journal of Humanities \& Social Sciences) U.S.A

http://www.ijhssnet.com/index.php?option=com_content\&view=article\&id=55\&Itemid=10 